\title{
News from the Society
}

- Library of Law, Medicine \& Health Care

- Program Planning Committee

- Annual Membership Meeting Proposed

The Library

In December, the Society formally established the Elliot L. and Annette Y. Sagall Library of Law, Medicine \& Health Care - a unique bibliographic resource on medicolegal issues and health law. The process of cataloguing the extensive collection donated to the Society by Dr. Sagall began in September of 1979, and on December 7 1979 , a reception was held to introduce this new facility to professional school deans and librarians, hospital administrators and librarians, medicolegal professionals, and members of the Society's Council and the Library's ad hoc Planning Committee.

The Sagall Library will become an information clearinghouse devoted to the interrelationships between the legal system and the health care delivery system, including its financing component. It will supplement the excellent professional school libraries in the Greater Boston area and meet the need for a specialized resource and information collection on medicolegal issues. Included will be such topics as: biomedical ethics, health care regulation, hospital law, workers' compensation, children's rights, and the forensic sciences. The scope of the topics covered is identical to that used in the Medicolegal Reference Shelf section of MEdicolegal NewS

The Library will function as a vital component of the American Society of Law \& Medicine and will augment the Society's publications - the AMERICAN JOURNAL OF LAW MEDICINE, MEDICOLEGAL NEWS, and NURSING LAW \& ETHICS - as well as its educational conference series and the newly established ASLM Speakers' Bureau. Initially, the Medicolegal Reference Shelf section of MEdiCOLEGAL NEWS will serve as a "new acquisitions" listing for the Library.

The Sagall Library of Law, Medicine \& Health Care was established by the American Society of Law \& Medicine in furtherance of the Society's goal of continuing medicolegal education on a multidisciplinary basis. In 1978 , the Executive Committee of the Society recognized the need for a specialized medicolegal library and authorized an ad hoc Planning Committee, co-chaired by Professor William J. Curran, of Harvard Medical School and Harvard
School of Public Health, and Elliot $L$. Sagall, M.D., co-founder and President of the American Society of Law \& Medicine, to explore and develop plans for the Library. The present facility is the initial realization of the project. By an unanimous vote of those present at the September 1979 meeting of the ASLM Council, it was decided that the new facility would be named for Elliot L. Sagall, M.D., and his wife Annette in recognition of their extensive and tireless efforts to further the goals of the Society.

The Sagall Library of Law, Medicine \& Health Care is presently being funded out of the regular operating funds of the American Society of Law $\&$ Medicine, that is, the dues paid by our more than 2200 members. To date, attempts to solicit private foundation funding have not met with success, but a grant request is presently pending with the National Library of Medicine wherein the Library proposes to develop fully its resources and to disseminate the collected information to health care professionals across the nation. Other efforts to secure outside funding are being pursued including establishing institutional affiliations with local professional schools who may desire to make the Library facility and resources available to their students and faculty who are not regular members of the Society. All suggestions as to potential funding sources are welcomed as are your tax-deductible contributions to further the goals and services of the Library.

\section{Current Resources}

The Sagall Library of Law, Medicine \& Health Care is composed of essentially two sets of materials: 1) books and pamphlets, and 2) periodical articles, court decisions, and other reference materials.

The present book collection of the Library is almost entirely the gift of Elliot and Annette Sagall. The collection comprises over 1800 volumes, some of which are duplicates, and it is catalogued according to customary library schemes, including title, author, and subject matter cards. The cataloguing task is nearing completion. It was conducted primarily by Society staff members Denise Provost and Diane Davis, and by Ross Lundquist, a cataloguer at the Countway Medical Library at Harvard Medical School, whose paid services were made available to the Library through the cooperation of Robin LeSueur, the Head Librarian at Countway.
The other major set of materials in the Library is the continuing collection of periodical articles, court decisions, pamphlets, and other items collected for and cited in the Medicolegal Reference Shelf section of each issue of Medicolegal News. During 1979, the four issues of MEdicolegal News listed over 950 items arranged according to the same subject matter topics utilized by the Library. The Library has the cumulative list of these, and many more, and provides a unique research source. Since mid-1979, the Society has offered a Photocopy Service which makes copies of many of the articles and items cited in the Medicolegal Reference Shelf available to readers of MEDICOLEGAL NEwS.

The Library hopes to expand this service in order that members outside of the Boston area and others who have difficulty utilizing the facility may still avail themselves of its resources.

\section{Access to the Library}

Until adequate on-site user space and additional funding can be secured, use of the Library will be limited to members of the Society. Members of the Society will be allowed on-site ac. cess to the Library's materials during regular business hours. Members will also be permitted to phone or write in requests for bibliographic reference assistance on specific problems. Socjety staff will review the collection for appropriate books, periodical articles, or court decisions, and copies of relevant materials may be purchased through the Photocopy Service. A separate circulation collection will be identified and members will be allowed to borrow, by mail if postage is pre-paid, the books included in this collection. MEDICOLEGal NEWs will provide the vehicle for advising Society members which books are available for borrowing.

In order to make the resources of the Sagall Library available to nonSociety members, a series of affiliation arrangements have been established. Professional schools, hospitals, law firms, non-profit organizations, and insurance companies will be advised of the Library and their faculty, students, or employees will be permitted full use of the Library facility and services in return for an annual fee. The following benefits will be made available to nonSociety members through institutional affiliations:

a) on-site access

(continued on page 18) 


\section{Correspondence (continued)}

It is hoped that the status quo of licensure can be eliminated and progress made to recognize the qualified athletic trainer as the professional he is.

Sincerely,

Joe Gieck, Ed.D., ATR, RPT

Curriculum Director

Head Athletic Trainer

Division of Sports Medicine

and Athletic Training

University of Virginia

\section{Dear Editor:}

In response to the letter from Frances Kolbmann, ART, concerning the retention of the medical records of a closed hospital, there is a Washington state statute relating to disposition of records for hospitals that close. It is part of a record retention act and cov. ers hospitals and nursing homes. Specifically, it reads:

If a hospital ceases operations, it shall make immediate arrangements, as approved by the department (Department of Social and Health Services, a state governmental agency, similar to other state health departments) for preservation of its records.

The implementing Administra. tive Code states:

If a hospital ceases operation, it shall make immediate arrangements for preservation of its medical records and other records of or reports on patient care data in accordance with applicable state statutes and regulations. The plan for such arrangements shall have been approved by the Department (Department of Social \& Health Services) prior to the cessation of operation.

Since specific retention periods are defined for medical records, there is no question as to the requirement to preserve for at least that length of time. We have had no hospital close since the legislation was passed, but it was writ- ten in because one had closed prior to that time, with problems arising due to lack of a statute. The same wording was used to include nursing homes in that bill, the greatest problems having arisen at that level.

The suggestion that a newspaper announcement be placed to notify patients of the upcoming destruction of their records, with adequate lead time to permit recovery, seems a most viable one, certainly the least expensive. This might be followed by a request for preservation in the state archives of the remaining records, with a specified time for destruction. Putting this up to the state's health department might be a step in solving the problem once and for all, if some decision, such as placement in state archives, could at least be part of the hospital licensing laws of the state.

Mrs. Lynn Regudon, RRA

Director, MRT Program

Shoreline Community College Seattle, Washington

\section{News from the Society (continued from page 16)}

b) limited bibliographic research assistance by telephone request

c) access to photocopy service

d) circulation of duplicate copies of books

e) librarian members will also be permitted to duplicate the entire card catalogue of the Library for reference by their own users.

The following fee structure has been established for 1980 :

- librarians

- group (3-5 persons)

- professional schools

(all students and faculty)

For more information on the $\mathbf{L i}$ brary, its collection, and services, please contact Edward Doudera, Esq., Executive Director, American Society of Law \& Medicine, 520 Commonwealth Avenue, Boston, MA 02215 , (617) 262-4990.

Conference Advisory Committee As the conference program of the Society expands, it is essential that the involvement of Society members in the planning process increase. Accordingly, a Program Planning Advisory Committee has been authorized by the Executive Committee of the Society. This Committee will serve as a re- source to evaluate suggested conference topics and the substantive content of proposed programs. It will also nominate faculty participants and otherwise contribute to the Society's series of educational programs.

All members of the Society are eligible for appointment to this Committee. Interested persons should write Elliot L. Sagall, M.D., in care of the Society, mentioning their primary areas of expertise.

\section{Annual Membership Meeting} Proposed

On a related topic, it has been suggested that the Society plan and sponsor an annual meeting of the membership. Because of the diverse interests of the Society's membership, such a meeting would necessarily combine plenary and a variety of concurrent sessions on a wide range of medicolegal issues. Hawaii has been proposed as the site for the meeting and space has been tentatively reserved for early December 1981. All members are asked to communicate their interest in attending or participating in such a meeting and the issues they would like covered to Edward Doudera, Esq., Executive Director of the Society.
Stress, Strain, Heart Disease and the Law

The Proceedings of the Conference on Stress, Surain, Heart Disease and the Law are still available. The 217page paperback book resulted from the January 1978 conference which was sponsored by the American Society of Law \& Medicine, the American Heart Association, the President's Committee on Employment of the Handicapped, and the Massachusetts Affiliate of the American Heart Association.

Included are such topics as: Medical and Legal Assessments of Causality in Heart Disorders; The Role of Coronary Risk Factors; Physical Activity and Heart Disease; Physical Activity and Sudden Death; The Long Term Effects of Physical Activity and Heart

Disease; Exercise Testing and the Assessment of Cardiovascular Disability; and the Relationship Between Emotional Stress and Illness Onset.

To order your copy, send your name, mailing address, and a check for $\$ 2.50$ (to cover postage and handling) to: American Society of Law \& Medicine, 520 Commonwealth Avenue, Boston, MA 02215. 